Vol. 15, No. 1, pp. 1-8

\title{
KINETICS AND ISOTHERM STUDIES ON ADSORPTION OF HEXAVALENT CHROMIUM USING ACTIVATED CARBON FROM WATER HYACINTH
}

\author{
Angelica Macalalad ${ }^{1} \otimes$, Quennie Rose Ebete ${ }^{1}$, Dominic Gutierrez', \\ Madelaine Ramos ${ }^{1}$, Bryan John Magoling ${ }^{1}$
}

https://doi.org/10.23939/chcht15.01.001

\begin{abstract}
The present study is focused on the use of activated carbon derived from water hyacinth (WH-AC) as adsorbent for the removal of $\mathrm{Cr}(\mathrm{VI})$ from aqueous solution. The optimized $\mathrm{WH}-\mathrm{AC}$ was found to be mesoporous and considered as granular. The surface area of $11.564 \mathrm{~m}^{2} / \mathrm{g}$ was found to have a good adsorption capacity. The adsorption data of the optimized WH-AC followed a pseudo-second order kinetics and the Freundlich isotherm model. Based on the correlation coefficient obtained from pseudo-second-order kinetic model, the $R^{2}$ values were all above 0.99 , which is closer to unity of one (1) indicating that it followed a chemisorption process. The adsorption capacity of WH-AC increased from 1.98 to $4.68 \mathrm{mg} / \mathrm{g}$ when adsorbate concentration increased from 20 to $50 \mathrm{mg} / \mathrm{l}$. The overall study proved that the adsorption by activated carbon derived from water hyacinth can be an alternative and efficient technique in hexavalent chromium removal.
\end{abstract}

Keywords: adsorption, hexavalent chromium, kinetics, isotherm, water hyacinth.

\section{Introduction}

On May 2013, the Environment Health Perspectives reported that hexavalent chromium or $\mathrm{Cr}(\mathrm{VI})$ was one of the most toxic chemicals identified in India, Indonesia, and the Philippines [1]. Because of its high toxicity and carcinogenic nature, the U.S. Environmental Protection Agency (US-EPA) had set the maximum allowable limit of $\mathrm{Cr}(\mathrm{VI})$ in surface water to $0.1 \mathrm{ppm}$, while the maximum permissible level of $\mathrm{Cr}(\mathrm{VI})$ in drinking water set by the World Health Organization (WHO) is $0.05 \mathrm{ppm}$ [2]. In view of this, the chromium concentration in aquatic environment has been one of the main concerns in environmental management due to its detrimental effect on humans.

\footnotetext{
${ }^{1}$ Chemistry Department, College of Arts and Sciences,

Batangas State University, Batangas City, Philippines

\19angelica76@gmail.com

(C) Macalalad A., Ebete Q.R., Gutierrez D., Ramos M., Magoling B.J., 2021
}

Chromium and its compounds are widely and primarily used in metallurgy, leather tanning, chrome plating, wood treatment, and paint pigment [3]. It exists in two forms: $\mathrm{Cr}(\mathrm{III})$ and $\mathrm{Cr}(\mathrm{VI})$, considering the hexavalent form as generally more toxic due to its solubility and can be easily absorbed and accumulated in the body. The extensive use of chromium leads to detrimental impact on the environment and has become a serious health problem.

Taking into account the different hazards of $\mathrm{Cr}(\mathrm{VI})$, it is essential to apply treatment before discharging the wastewater into the aquatic environment. The common methods for $\mathrm{Cr}(\mathrm{VI})$ removal include ion exchange, reduction, reverse osmosis, electrodialysis, and adsorption. Drawbacks were encountered in most of these techniques, for example incomplete removal of the residual metal sludge and high operational costs. Among the methods, adsorption using activated carbon (AC) is highly effective and economical because the adsorbent can be regenerated by suitable desorption process and has excellent adsorption properties. More so, AC can be prepared from a variety of agricultural wastes.

The objective of the study was to characterize and determine the physical and chemical properties of activated carbon from water hyacinth for the removal of $\mathrm{Cr}(\mathrm{VI})$ in simulated wastewater. The adsorption capacity of the WH$\mathrm{AC}$ in simulated wastewater was also investigated upon varying initial concentration and contact time. The adsorption data of the activated carbon were fitted against adsorption isotherm and kinetic models.

\section{Experimental}

\subsection{Preparation of Water Hyacinth- Activated Carbon (WH-AC)}

The water hyacinth samples were collected from Agoncillo, Batangas, Philippines. Activated carbon was prepared from the stems of water hyacinth using the researchers' previously optimized protocol, determined using response surface methodology (RSM). 
The stems of the water hyacinth were washed with distilled water, then sun-dried for three days and then dried in the oven at $378 \mathrm{~K}$ for $24 \mathrm{~h}$. The dried water hyacinth stems were carbonized, ground and sieved. The chemical activation was done by treating the carbonized sample with $40 \% \mathrm{H}_{3} \mathrm{PO}_{4}$ in an impregnation ratio of $1: 5$ for $2 \mathrm{~h}$ at $353 \mathrm{~K}$. Afterwards, the thermal treatment was carried out using a muffle furnace at $873 \mathrm{~K}$ for $90 \mathrm{~min}$. For $\mathrm{pH}$ adjustment, $1 \mathrm{M} \mathrm{HCl}$ and $1 \mathrm{M} \mathrm{NaOH}$ were used upon washing with hot distilled water. The WH-AC was oven dried, cooled and stored in air-tight containers for further use.

\subsection{Preparation of Aqueous Solutions}

A stock chromium solution with the concentration of $500 \mathrm{mg} / \mathrm{l}$ was prepared by dissolving a sufficient amount of potassium dichromate in distilled water. The standards and solutions for the adsorption experiments were obtained by diluting the stock solution to the desired concentrations. All chemicals utilized in this work were of analytical reagent (AR) grade.

\subsection{Characterization of WH-AC}

The surface functional groups of WH-AC were determined using a Nicolet 6700 (Thermo Nicolet Co., Madison, WI, USA) Fourier-Transform infrared (FTIR) spectrophotometer. The surface morphology was investigated using a JSM-5310 (JEOL Ltd., Tokyo, Japan) scanning electron microscopy (SEM). The surface area, pore volume, and pore radius were measured using a volumetric adsorption analyzer (Quantachorome, Bayton Beach, FL, USA). The BET surface area was computed using the Brunauer-Emmet-Teller (BET) equation.

\subsection{Batch Adsorption Studies}

The batch adsorption process was performed for the hexavalent chromium adsorption onto the produced WH-AC. Each flask contained $100 \mathrm{ml}$ of $\mathrm{Cr}(\mathrm{VI})$ aqueous solution of desired concentration. The produced WH-AC samples $(0.1 \mathrm{~g})$ were added to the individual flasks, which were then agitated with an isothermal shaker set at $303 \mathrm{~K}$ and $200 \mathrm{rpm}$ until the equilibrium time of $60 \mathrm{~min}$ was reached. After agitation, the samples were filtered immediately using Whatman \#1 filter paper to segregate the adsorbent from the solution. During the filtration, the samples were divided into two parts. The first part was used to saturate the filter paper to avoid the effects of adsorption onto the filter paper and the filtrate was disregarded. The residual $\mathrm{Cr}(\mathrm{VI})$ concentrations in the filtrate from the second portions were measured using UVVisible spectrophotometer at $540 \mathrm{~nm}$ upon compleximetric reaction with 1,5-diphenylcarbazide at $\mathrm{pH} 2.0$. The adsorbed $\mathrm{Cr}(\mathrm{VI})$ concentrations were obtained from the difference between the initial and final concentrations in the solution, while the percentage removal at equilibrium was calculated based on Eq. (1):

$$
\% \mathrm{Cr}^{6+} \text { Removal }=\frac{\left(C_{0}-C_{e}\right)}{C_{0}} \cdot 100 \%
$$

where $C_{0}$ and $C_{e}$ are the liquid-phase concentrations of the initial state and at equilibrium, respectively, $\mathrm{mg} / \mathrm{L}$.

The amount of $\mathrm{Cr}(\mathrm{VI})$ adsorbed per unit mass of the produced activated carbon at equilibrium time $\left(q_{e}\right.$, $\mathrm{mg} / \mathrm{g}$ ) was calculated using Eq. (2):

$$
q_{e}=\frac{\left(C_{0}-C_{e}\right) \cdot V}{m}
$$

where $q_{e}$ is the amount of $\mathrm{Cr}(\mathrm{VI})$ adsorbed per unit weight of adsorbent, $\mathrm{mg} / \mathrm{g} ; C_{0}$ and $C_{e}$ are the liquid-phase concentrations of adsorbate at the initial and equilibrium conditions, respectively, $\mathrm{mg} / \mathrm{l} ; V$ is the volume of the solution, 1 ; and $m$ is the mass of the produced activated carbon used, $g$ [4].

\subsection{Adsorption Isotherm}

In this study, the Langmuir and Freundlich models were employed to describe the adsorption mechanism of $\mathrm{Cr}(\mathrm{VI})$ onto the surface of WH-AC.

Langmuir model. The Langmuir model is centered on the assumption that adsorption energy is constant and independent of surface coverage. Maximum adsorption happens once the surface is masked by a monolayer of adsorbate [5]. The linear form of the Langmuir isotherm equation is expressed based on Eq. (3):

$$
\frac{1}{q_{e}}=\frac{1}{Q b C_{e}}+\frac{1}{Q}
$$

where $C_{e}$ is the equilibrium liquid-phase concentration of metals, $\mathrm{mg} / \mathrm{l} ; q_{e}$ is the equilibrium uptake capacity, $\mathrm{mg} / \mathrm{g}$; $Q$ is the Langmuir constant related to adsorption capacity, $\mathrm{mg} / \mathrm{g}$; and $b$ is the Langmuir constant related to the energy of the sorption, which quantitatively reflects the affinity between the sorbent and the sorbate, $1 / \mathrm{mg}$.

Freundlich model. The Freundlich model is based on sorption on a heterogeneous surface of varied affinities. The linear form of Freundlich model is given as Eq. (4):

$$
\log q_{e}=\log K_{f}+\frac{1}{n} \log C_{e}
$$

where $q_{e}$ is the amount of metals adsorbed at equilibrium, $\mathrm{mg} / \mathrm{g} ; C_{e}$ is the adsorbate concentration, $\mathrm{mg} / \mathrm{l} ; K_{f}$ is the Freundlich constant related to adsorption capacity, $(\mathrm{m} / \mathrm{g}) \cdot(1 / \mathrm{mg})^{1 / n}$; and $1 / n$ is the Freundlich constant related to sorption intensity of the sorbent [6].

\subsection{Adsorption Kinetics}

The adsorption kinetics studies were done in order to describe the rate of $\mathrm{Cr}(\mathrm{VI})$ uptake on to the $\mathrm{WH}-\mathrm{AC}$ and provided major insight into the adsorption mechanism 
and the possible rate-controlling processes example chemical reaction and mass transfer [7]. The governing mechanism of the adsorption process was observed by fitting the experimental results with pseudo-first order and pseudo-second order kinetics models.

Pseudo-first order model. The adsorption of liquidsolid systems based on the solid capacity follows a pseudo-first order model [8]. Generally, the pseudo-first order kinetic model is only applicable for the initial stage of the adsorption process. The linear form of the pseudofirst order rate equation is illustrated by the following equation:

$$
\log \left(q_{e}-q_{t}\right)=\log q_{e}-\frac{k_{1}}{2.303} t
$$

where $k_{1}$ is the pseudo-first order adsorption rate constant, $1 / \mathrm{min} ; q_{e}$ and $q_{t}$ are the amounts of the adsorbed $\mathrm{Cr}(\mathrm{VI})$ at the equilibrium time and at time $t(\mathrm{~min})$, respectively, $\mathrm{mg} / \mathrm{g}$.

Pseudo-second order model. The pseudo-second order model predicts the adsorption mechanism over a range of different points in time during the adsorption process. The pseudo-second order model equation is given as:

$$
\frac{t}{q_{t}}=\frac{1}{k_{2} q_{e}^{2}}+\frac{1}{q_{e}} t
$$

where $k_{2}$ is the equilibrium rate constant of the pseudosecond order model, $\mathrm{g} / \mathrm{mg} \cdot \mathrm{min}$.

\section{Results and Discussion}

\subsection{Physical and Chemical Properties of WH-AC}

\subsubsection{Functional groups}

Fig. 1 shows the FTIR spectrum of the WH-AC surface which possibly contains alkanes and alkenes,
$\mathrm{C}-\mathrm{O}-\mathrm{C}$ stretching vibrations, $\mathrm{C}-\mathrm{N}$ stretching vibrations, $\mathrm{C}=\mathrm{C}$ bonding aromatic skeletal, $\mathrm{C}=\mathrm{O}$ stretching in ester, and $\mathrm{O}-\mathrm{H}$ stretching vibrations.

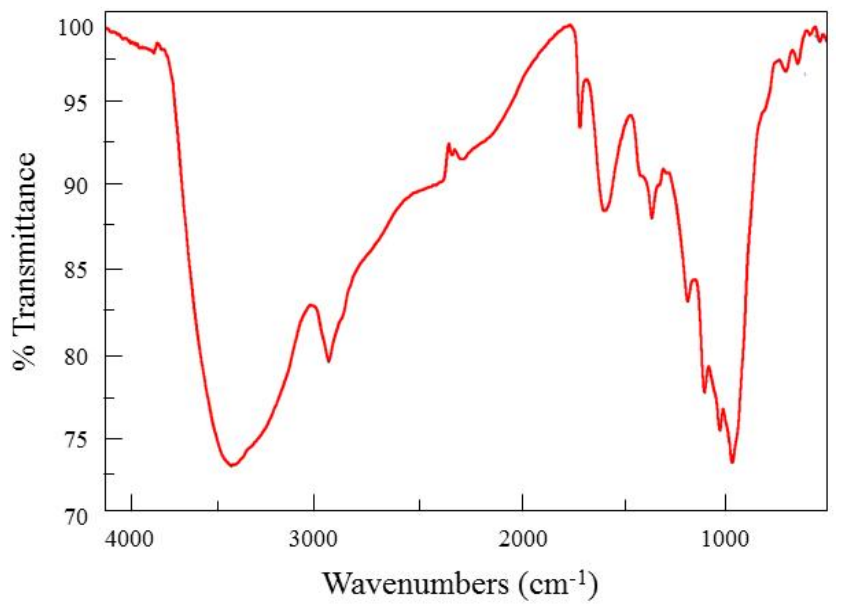

Fig. 1. FTIR spectrum of WH-AC produced under optimum activation conditions

Table 1 shows the absorbance bands obtained from FTIR spectrum of WH-AC under the optimum activation conditions and its possible functional groups assignment. Based on Fig. 1, a broad peak between 3600 and $3200 \mathrm{~cm}^{-1}$, with the maximum peak at about $3386.90 \mathrm{~cm}^{-1}$ is attributed to $\mathrm{O}-\mathrm{H}$ stretching vibrations, since absorption peaks around 3030.6 and $3423.0 \mathrm{~cm}^{-1}$ indicate the presence of free and intermolecular bonded hydroxyl groups [9]. Peaks ranging from 3000 to $2850 \mathrm{~cm}^{-1}$ can be assigned to strong stretching vibrations of alkane $\mathrm{C}-\mathrm{H}$ bonds and the peak around $2927.61 \mathrm{~cm}^{-1}$ can be assigned to the presence of aldehydes, carbonyls, carboxylic acid, and esters on the surface. Peak at $1740.89 \mathrm{~cm}^{-1}$ can be assigned to ester $\mathrm{C}=\mathrm{O}$ stretch [10].

\begin{tabular}{|c|c|c|c|}
\hline Sample & Range, $\mathrm{cm}^{-1}$ & Peak, $\mathrm{cm}^{-1}$ & Possible assignments \\
\hline \multirow{7}{*}{ WH-AC } & $1100-600$ & $\begin{array}{c}1079.97 \\
1021.15 \\
769.36 \\
712.32 \\
654.24 \\
607.10 \\
578.31\end{array}$ & Alkanes and alkenes \\
\hline & $1200-1000$ & $\begin{array}{l}1231.81 \\
1152.31\end{array}$ & $\begin{array}{l}\mathrm{C}-\mathrm{O}-\mathrm{C} \text { stretching vibrations in aromatic esters } \\
\mathrm{C}-\mathrm{N} \text { stretching vibrations of aliphatic amines }\end{array}$ \\
\hline & $1600-1400$ & 1401.03 & Aromatic ring or $\mathrm{C}=\mathrm{C}$ bonding \\
\hline & $1680-1580$ & 1621.58 & Aromatic skeletal stretching \\
\hline & 1740 & 1740.89 & $\mathrm{C}=\mathrm{O}$ stretching in ester \\
\hline & $3000-2850$ & 2927.61 & Strong stretching vibrations of saturated systems (alkanes, $\mathrm{sp}^{3}$ ) \\
\hline & $3600-3100$ & 3386.90 & $\mathrm{O}-\mathrm{H}$ stretching vibrations \\
\hline
\end{tabular}

Peak assignments of surface functional groups in WH-AC produced under optimum activation conditions 
Peaks ranging from 1680 to $1580 \mathrm{~cm}^{-1}$, with the maximum at $1621.58 \mathrm{~cm}^{-1}$ are attributed to aromatic skeletal stretching. Stretching vibration at $1600-1400 \mathrm{~cm}^{-1}$ corresponds to the aromatic ring or $\mathrm{C}=\mathrm{C}$ bonding with the maximum peak of $1401.03 \mathrm{~cm}^{-1}$. Peaks at $1200-1000 \mathrm{~cm}^{-1}$ with the maxima at 1231.81 and $1152.31 \mathrm{~cm}^{-1}$ are for $\mathrm{C}-$ $\mathrm{O}-\mathrm{C}$ stretching and $\mathrm{C}-\mathrm{N}$ stretching vibrations. Peaks ranging from 1100 to $600 \mathrm{~cm}^{-1}$ may suggest alkanes and alkenes with peaks at 1079.97, 1021.15, $769.36 \mathrm{~cm}^{-1}$ and $712.32,654.24,607.10,578.31 \mathrm{~cm}^{-1}$, respectively [9]. These functional groups have a high affinity towards hexavalent chromium.

In the FTIR spectrum illustrated in Fig. 1, there is a broad peak between 3600 and $3100 \mathrm{~cm}^{-1}$ and a maximum peak at about $3413.47 \mathrm{~cm}^{-1}$. The peak represents the $\mathrm{O}-\mathrm{H}$ stretching vibrations band. The band may be due to the surface hydroxyl groups from carboxyls, phenols, or alcohols and chemisorbed water due to hydrogen bonding [11]. Peaks ranging from 3000 to $2850 \mathrm{~cm}^{-1}$ may be due to the strong stretching vibrations of saturated systems such as alkanes $\left(\mathrm{sp}^{3}\right)$ [12]. The $\mathrm{C}-\mathrm{N}$ stretching vibrations of aliphatic amines can also be incorporated in this region, which is consistent with the presence of primary amines with the peaks ranging from 1680 to $1580 \mathrm{~cm}^{-1}$ and a maximum at $1621.52 \mathrm{~cm}^{-1}$ [11].

Stretching vibration at $1600-1400 \mathrm{~cm}^{-1}$ corresponds to the aromatic ring or $\mathrm{C}=\mathrm{C}$ bonding. Presence of this functional group indicates the formation of carbonyl containing group and aromatization of the precursor [13]. A peak can also be seen at $1200-1000 \mathrm{~cm}^{-1}$, which can be due to the $\mathrm{C}-\mathrm{O}$ stretching vibrations band in alcohol, phenols, esters, or ethers. The maximum peak at $1089.13 \mathrm{~cm}^{-1}$ can be assigned to $\mathrm{C}-\mathrm{O}-\mathrm{C}$ stretching vibrations in aromatic esters. Peaks ranging from 600 to $1100 \mathrm{~cm}^{-1}$ are also noticed, which may suggest alkanes and alkenes [11]. The presence of hydroxyl groups and carbonyl groups evidences that the structure of WH-AC produced under optimum activation conditions contains lignocellulose.

This surface chemistry of WH-AC determines the surface properties of the carbon and significance of their behavior if used as ion exchangers, adsorbent catalyst or catalyst support [14].

\subsubsection{Surface morphology}

The surface morphology of the stem sample (SS), stem biochar (SB), optimized activated carbon (stem), are examined using the scanning electron micrograph with the magnification of $3500 \times$ as depicted in Fig. 2.

Fig. 2 shows the morphological changes with respect to shape and size. It is evident that the carbon particles are in the form of spheres with a wider angle of sizes. This observation implies that modification treatments of the samples make obvious changes in the surface morphology of the adsorbents [15].

The surface of the raw material (SS) is fairly smooth, with very little pores. The stem biochar (SB) has some irregular cavities formed during the carbonization process. The surface topology between the raw samples and the optimized activated carbon is evidently different. A high porosity and homogenous structure with deep pores are observed on the surface of WH-AC after chemical and thermal activation. The pores result from the evaporation of the chemical reagent $\left(\mathrm{H}_{3} \mathrm{PO}_{4}\right)$ during thermal activation, leaving empty spaces [9]. The surfaces of the optimized WH-AC show mesoporous surfaces with few micropores and macropores, which is desirable for the adsorption of pollutants such as heavy metals [14].
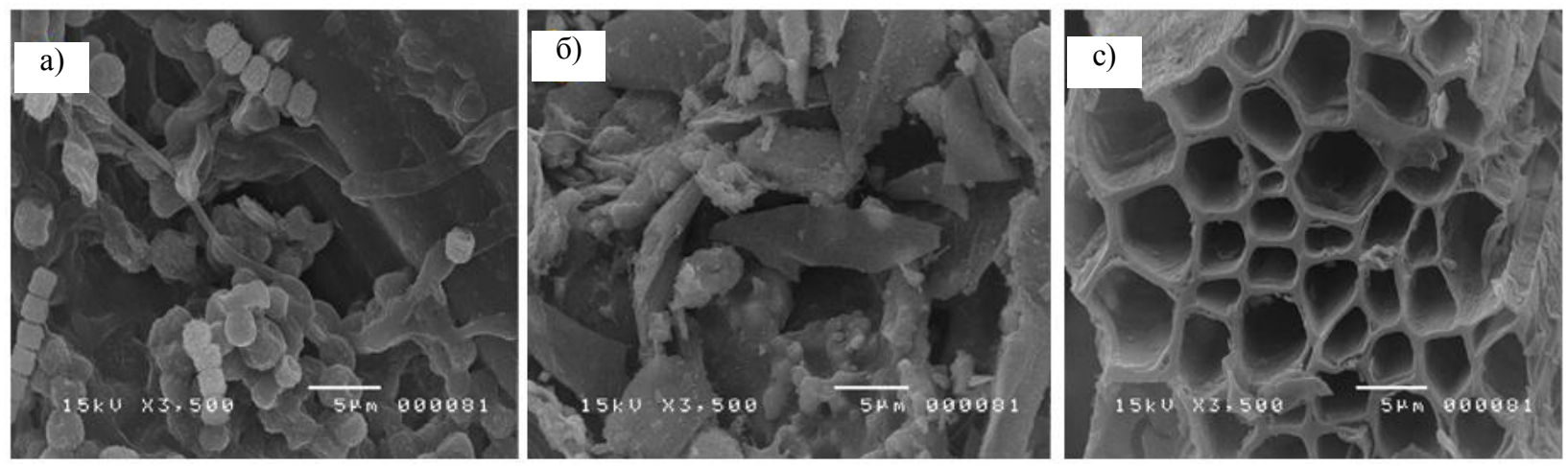

Fig. 2. SEM micrographs of the stem sample (a); stem biochar (b) and optimized activated carbon (Stem) (c) with magnification of $3500 \times$ 


\subsubsection{Surface area, pore volume, pore diameter and particles size}

Table 2 presents the properties of the WH-AC in terms of surface area, pore radius, pore volume, and particles size.

Table 2

\section{Surface characteristics of the WH-AC produced under optimum activation conditions}

\begin{tabular}{|c|c|}
\hline Surface area, $\mathrm{m}^{2} / \mathrm{g}$ & 11.564 \\
\hline Pore volume, $\mathrm{cc} / \mathrm{g}$ & 0.024 \\
\hline Pore diameter, $\AA$ & 38.090 \\
\hline Particles size $(\mathrm{mesh})$ & 100 \\
\hline
\end{tabular}

Even though the WH-AC has a small surface area of $11.564 \mathrm{~m}^{2} / \mathrm{g}$ it was found to have good adsorption capacity [16]. This can be explained by the fact that a large number of vacant surface sites are available for adsorption of metal ions but with passage of time the surface sites become exhausted [17]. It is also accessible to the passage of a fluid or vapour if adsorption is to exist and the activated carbon is accessible to the surface via a network of pores of differing diameters. Thus, the WH$\mathrm{AC}$ was also capable of adsorbing hexavalent chromium in relation to its surface area. The volume of the activated carbon is relatively small and lies between 0.02 and $0.10 \mathrm{cc} / \mathrm{g}$, corresponding to a specific surface area of 10 $70 \mathrm{~m}^{2} / \mathrm{g}$. The pore volume of the activated carbon from water hyacinth is found to be of $0.024 \mathrm{cc} / \mathrm{g}$.

The presence of mesopores in WH-AC is very important from the water treatment point of view, because mesoporous structure allows water or wastewater to penetrate into activated carbon and to get in contact with the micropores in order to permit the adsorption of heavy metals and pollutants of high molecular weight such as organic compounds [18]. The presence of mesopores and macropores serves as the passage to the adsorption sites.

The developed pore structure provides a higher probability for $\mathrm{Cr}(\mathrm{VI})$ entrapment and adsorption onto the surface of the WH-AC produced under optimum activation conditions.

Based on Table 2, the pore radius of WH-AC is found to be $19.045 \AA$. The importance of measuring the characteristics, such as pore radius of an adsorbent, is the relative dependence of its adsorption capacity to these properties [11]. Mesopores are those in which capillary condensation with the formation of a meniscus of the liquefied adsorbate take place. The curvature radii of the surface of mesopores lie between 16 and $1000 \AA$ [19].

The WH-AC has a mesh size of 100 which is equivalent to $0.297 \mathrm{~mm}$. Thus, the optimized activated carbon is a granular activated carbon (GAC). GAC is employed in water treatment plant after the preliminary disinfection process [20]. The carbon particle size influences the adsorption rate providing quicker rates of adsorption but not the adsorptive capacity that contributes mainly to a system's hydraulics, filterability and handling characteristics. Granular activated carbons have advantages of being harder and longer lasting than powdered activated carbons, clean to handle, purify larger volumes of liquids, and can be reactivated and reused many times. The granular activated carbon holds a particular promise in the removal of metal ions from aqueous solutions [21].

\subsection{Adsorption Capacity at Varying Initial Adsorbate Concentration and Varying Contact Time}

The adsorption capacity with respect to contact time $(10-60 \mathrm{~min})$ is shown in Fig. 3.

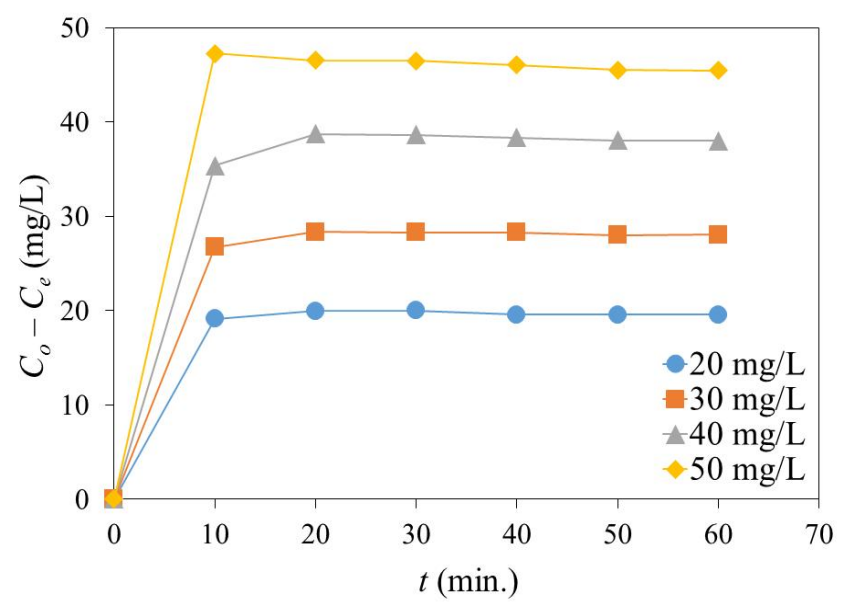

Fig. 3. Adsorption capacity at varying initial adsorbate concentration and varying contact time

Adsorption is rapid at the start because of the accessibility of active sites and the high concentration amount of WH-AC between the active sites and the aqueous solution. Once the surface begins to saturate, the rate of adsorption is restricted by the internal mass transfer of the adsorbate from the surface to the interior of the WH-AC particles [22]. The remaining low concentration has decreased mass transfer driving force, hence gradually occupying active sites with lower affinity until equilibrium condition was reached and the rate of desorption increased, causing the overall adsorption rate to decrease [23]. Equilibrium is achieved in $40 \mathrm{~min}$ for $20 \mathrm{mg} / \mathrm{l}$ and in $50 \mathrm{~min}$ for 30,40 and $50 \mathrm{mg} / \mathrm{l}$. Higher concentration requires longer contact time to attain equilibrium because of the higher amount of $\mathrm{Cr}(\mathrm{VI})$ molecules. The adsorption capacity with increasing contact time remains constant when equilibrium condition is established. 
The effect of contact time on the removal of $\mathrm{Cr}(\mathrm{VI})$ ions from aqueous solution of initial concentration 20, 30, 40 and $50 \mathrm{mg} / \mathrm{l}$ by adsorption on the prepared activated carbon sample is shown above. It also presents the adsorption capacity of the $\mathrm{WH}-\mathrm{AC}$ at varying initial adsorbate concentration $(20,30,40$ and $50 \mathrm{mg} / \mathrm{l})$ and varying contact times $(10,20,30,40,50$ and $60 \mathrm{~min})$. The adsorption capacity goes up with increasing initial concentration. The experimental equilibrium adsorption capacity increased from 1.98 to $4.68 \mathrm{mg} / \mathrm{g}$ when the concentration increased from 20 to $50 \mathrm{mg} / \mathrm{l}$. A similar trend was observed in the study of Dula and coworkers [24], wherein the adsorption capacity for $\mathrm{Cr}(\mathrm{VI})$ increased from 9.87 to $59.23 \mathrm{mg} / \mathrm{g}$ as the initial concentration were

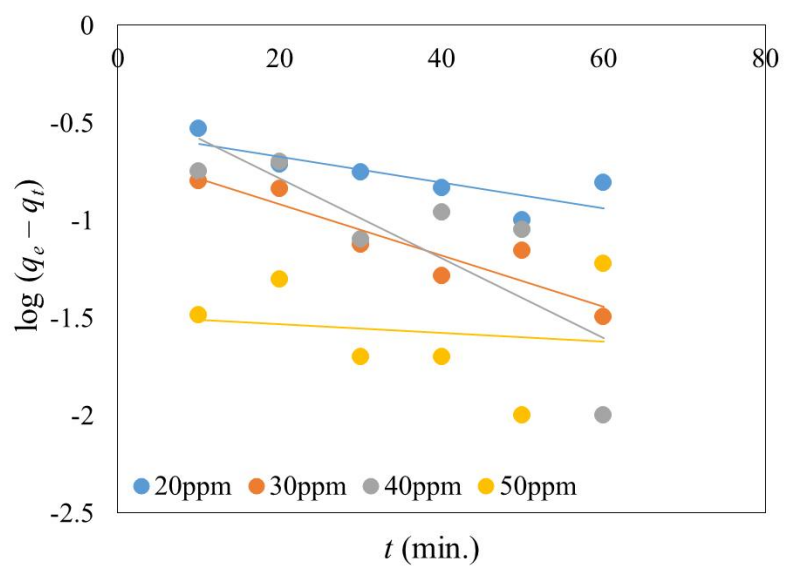

Fig. 4. Pseudo-first order kinetics (conditions: $\mathrm{pH} 2$; temperature $303 \mathrm{~K}$; WH-AC dosage $0.1 \mathrm{~g} / 100 \mathrm{ml}$ ) increased from 25 to $150 \mathrm{mg} / \mathrm{l}$. The rise in adsorption capacity is due to the larger mass transfer driving force between the aqueous and solid phases, resulting to better adsorption of $\mathrm{Cr}(\mathrm{VI})$ onto $\mathrm{WH}-\mathrm{AC}$ at a higher concentration.

\subsection{Adsorption Kinetics and Adsorption Isotherm Exhibited by the WH-AC}

To determine the adsorption kinetics of $\mathrm{Cr}(\mathrm{VI})$, two models are used: the pseudo-fist order and pseudo-second order models. The coefficients $k_{1}$ and $k_{2}$ are calculated using data from Figs. 4 and 5. The detailed parameters of the kinetic models are tabulated in Table 3.

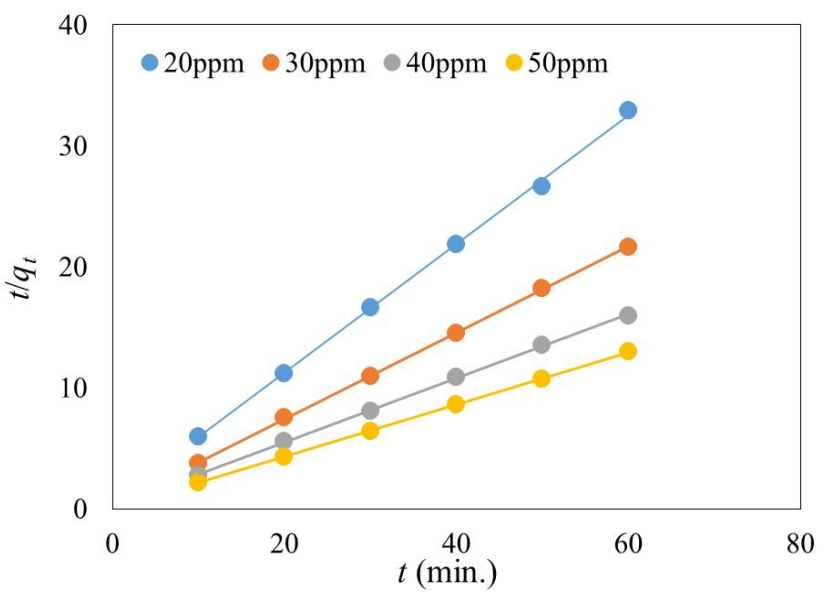

Fig. 5. Pseudo-second order kinetics (conditions: $\mathrm{pH}$ 2; temperature $303 \mathrm{~K}$; WH-AC dosage $0.1 \mathrm{~g} / 100 \mathrm{ml}$

Table 3

Kinetic parameters for chromium adsorption onto WH-AC

\begin{tabular}{|c|c|c|c|c|}
\hline \multirow{2}{*}{ Parameters } & \multicolumn{4}{|c|}{ Initial concentrations, ppm } \\
\hline & 20 & 30 & 40 & 50 \\
\hline$q_{e, \text { exp }}, \mathrm{mg} / \mathrm{g}$ & 1.98 & 2.81 & 3.78 & 4.68 \\
\hline \multicolumn{5}{|c|}{ Pseudo-first order } \\
\hline$k_{1}, 1 / \mathrm{min}$ & 0.0152 & 0.0303 & 0.0471 & 0.0051 \\
\hline$q_{e, \text { cal }}, \mathrm{mg} / \mathrm{g}$ & 0.2870 & 0.2217 & 0.4205 & 0.0323 \\
\hline$R^{2}$ & 0.6450 & 0.8585 & 0.6551 & 0.0206 \\
\hline \multicolumn{5}{|c|}{ Pseudo- second order } \\
\hline$k_{2}, 1 / \mathrm{min}$ & 0.5088 & 0.4578 & 2.4235 & -0.0172 \\
\hline$q_{e, \text { cal }}, \mathrm{mg} / \mathrm{g}$ & 1.8794 & 2.8026 & 3.7889 & 4.6368 \\
\hline$R^{2}$ & 0.9990 & 0.9998 & 0.9995 & 0.9999 \\
\hline
\end{tabular}

Note: pH 2; temperature 303 K; WH-AC dosage 0.1000 g/100 ml

The correlation coefficients $R^{2}$ for the pseudo-first order kinetic model are $0.0206-0.6450$; the $R^{2}$ values for the pseudo-second order kinetic model are all above 0.99 , which is closer to unity of 1 . Hence, the adsorption kinetics of chromium onto WH-AC is better described by the pseudo-second order kinetic model.

The results indicate that the first-order kinetic model is not applicable, since the correlation coefficient 
$R^{2}$ obtained with this approximation is relatively low. This is due to the fact that near equilibrium the experimental data deviate notably from the previous data obtained during the first stage of the experiment. The correlation coefficient obtained with the second-order approximation is, however, much higher $(\sim 1)$, which shows the suitability of the model.

However, for the pseudo-second order model, the experimental and the calculated $q$ values show compatibility. The higher $R^{2}$ and the smaller deviation values between the experimental and calculated $q$ establish that the pseudo-second order model is more suitable to describe the adsorption kinetics of $\mathrm{Cr}^{+6}$ on the WH-AC based activated carbon. Hence, the overall rate of adsorption process is governed by chemisorption, which involved valency forces through sharing or exchange of electrons between sorbent and sorbate [25].

As shown in Table 4, the low value of the relative error $(0.23-5.35 \%)$ between both adsorption capacities verifies the applicability of the pseudo-second order kinetic model.

The adsorption data were analyzed using the Langmuir and Freundlich models. In order to compare the isotherms, two graphs were plotted over the concentration range. The results are illustrated in Figs. 6 and 7.

Based on Fig. 7, it can be concluded that the adsorption equilibrium is best fitted for the Freundlich adsorption isotherm because of its highest value of correlation coefficient 0.978 compared to Fig. 6, Langmuir linear isotherm.

Table 4

\section{Kinetic model constants and correlation coefficients for adsorption of $\mathrm{Cr}^{+6}$ ions onto activated carbon} with varying initial concentration of chromium and varying contact time

\begin{tabular}{|c|c|c|c|}
\hline Initial concentration, $\mathrm{mg} / \mathrm{l}$ & $\begin{array}{c}q_{e}, \mathrm{mg} / \mathrm{g} \\
\text { (from experimental data) }\end{array}$ & $\begin{array}{c}q_{e}, \mathrm{mg} / \mathrm{g} \\
\text { (from second order model) }\end{array}$ & Relative error, \% \\
\hline 20 & 1.98 & 1.88 & 5.35 \\
\hline 30 & 2.81 & 2.80 & 0.26 \\
\hline 40 & 3.78 & 3.79 & 0.23 \\
\hline 50 & 4.68 & 4.64 & 0.93 \\
\hline
\end{tabular}

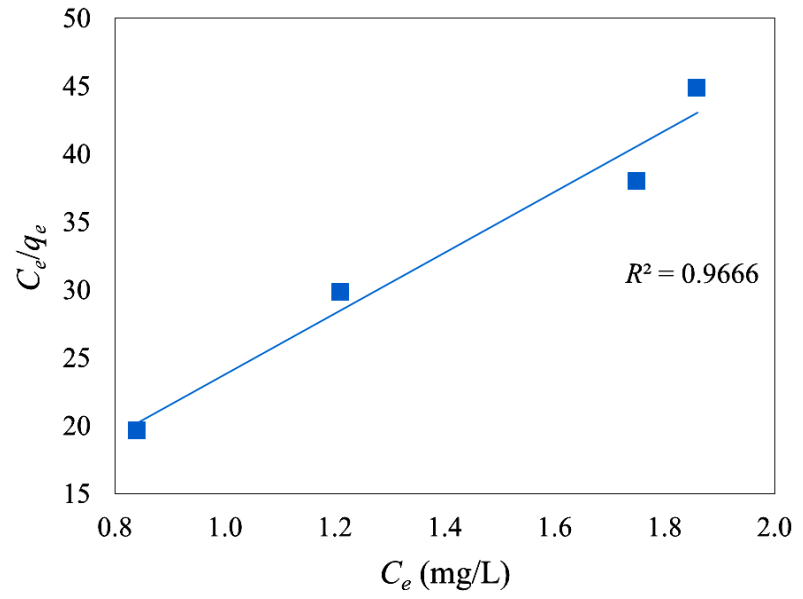

Fig. 6. Langmuir linear isotherm for $\mathrm{Cr}(\mathrm{VI})$ adsorption on WH-AC (particles size 100 mesh; temperature $303 \mathrm{~K}$; AC dose $0.1 \mathrm{~g} / 100 \mathrm{ml}$; pH 2)

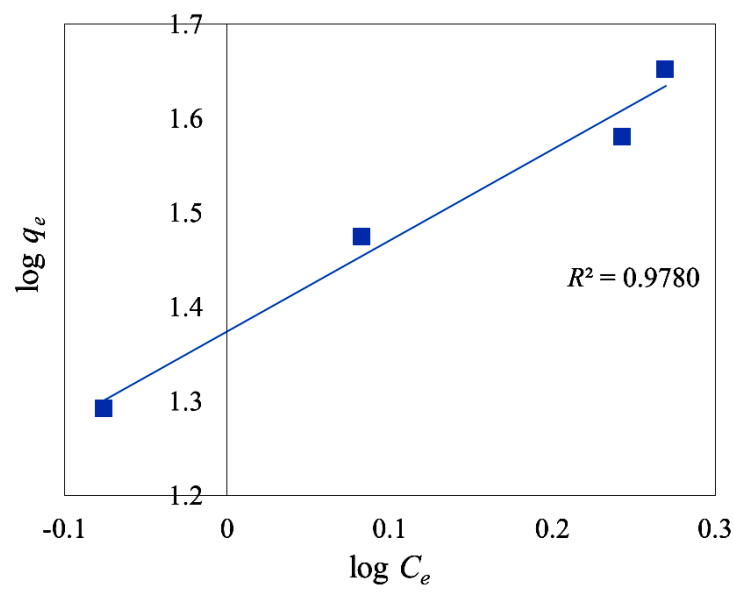

Fig. 7. Freundlich linear isotherm for $\mathrm{Cr}(\mathrm{VI})$ adsorption on $\mathrm{WH}-$ $\mathrm{AC}$ (particles size 100 mesh; temperature $303 \mathrm{~K}$; AC dose $0.1 \mathrm{~g} / 100 \mathrm{ml} ; \mathrm{pH} 2$ )

Table 5

\section{Adsorption isotherm model constants and correlation coefficients for adsorption of $\mathrm{Cr}^{+6}$ ions} onto activated carbon

\begin{tabular}{|c|c|c|c|c|c|}
\hline \multicolumn{3}{|c|}{ Langmuir } & \multicolumn{3}{c|}{ Freundlich } \\
\hline$k_{1}$ & $q_{\max }$ & $R^{2}$ & $K_{f}$ & $n$ & $R^{2}$ \\
\hline 16.2748 & 0.0447 & 0.9666 & 23.7 & 1.0366 & 0.9780 \\
\hline
\end{tabular}


The fact that the Freundlich model good fits to the experimental adsorption data suggests physical adsorption, as well as a heterogeneous distribution of active sites on the WH-AC surface. If the value of $n$ is equal to unity, the adsorption is linear. If the value of constant $n$ is below unity, it implies that the adsorption process is unfavorable, and if the value of $n$ is above unity, adsorption is favorable. Based on Table 7, the value of $n$ at equilibrium was above unity, suggesting favorable adsorption. Furthermore, the $K_{f}$ value is an indication of the WH-AC multilayer adsorption capacity.

\section{Conclusions}

The functional groups possibly present in the surface of WH-AC are alcohol, alkanes, alkenes, ester, carboxylic acid, aldehydes, carbonyls, amines, and alkyl halides. These functional groups have a high affinity towards hexavalent chromium. The WH-AC is mesoporous with few macropores and micropores suggesting a well-developed pore structure. The WH-AC produced under optimum activation conditions obtained low surface area, wide pore diameter, low pore volume, and small particle size.

The adsorption capacity increases along with increasing contact time and plateaus when equilibrium is established. At higher adsorbate concentrations, a longer contact time is required to adsorb the higher amount of $\mathrm{Cr}(\mathrm{VI})$ molecules in solution and to reach equilibrium.

The adsorption of $\mathrm{Cr}(\mathrm{VI})$ onto WH-AC best follows the Freundlich isotherm model and the pseudosecond order kinetics.

\section{References}

[1] https://eponline.com/articles/2013/05/06/people-affected-bytoxic-waste-sites.aspx

[2] Kakavandi, B., Kalantary, R. R., Farzadkia, M. et al.: J. Environ. Health Sci., 2014, 12, 115. https://doi.org/10.1186/s40201-0140115-5

[3] Rai M., Shahi G., Meena V. et al.: Resour. Efficient Technol., 2016, 2, S63. https://doi.org/10.1016/j.reffit.2016.11.011

[4] Alslaibi T., Abustan I., Ahmad M., Foul A.: J. Environ. Chem. Eng., 2013, 1, 589. https://doi.org/10.1016/j.jece.2013.06.028

[5] Langmuir I.: J. Am. Chem. Soc., 1916, 38, 2221.

https://doi.org/10.1021/ja02268a002

[6] Freundlich H.: J. Phys. Chem., 1906, 57, 385.

[7] Alslaibi T., Abustan I., Ahmad M., Foul A.: Desalin. Water Treat., 2015, 54, 166.

https://doi.org/10.1080/19443994.2013.876672

[8] Lagergren S.: Kungliga Svenska Vetenskapsakademiens Handlingar, 1898, 24, 1.

[9] Hesas R., Arami-Niya A., Daud W., Sahu J.: BioResources, 2013, 8, 2950. https://doi.org/10.15376/biores.8.2.2950-2966
[10] Țucureanu V., Matei A., Avram A.: Crit. Rev. Anal. Chem., 2016, 46, 502, https://doi.org/10.1080/10408347.2016.1157013

[11] Lafi R., Montasser I., Hafiane A.: Adsorpt. Sci. Technol.: 2018, 37, 160. https://doi.org/10.1177/0263617418819227

[12] Silverstein R., Webster F., Kiemle D. et al.: Spectrometric Identification of Organic Compounds. 8 edn. Wiley 2014.

[13] Anisuzzaman S., Joseph C., Daud W. et al.: Int. J. Ind. Chem., 2015, 6, 9. https://doi.org/10.1007/s40090-014-0027-3

[14] Magoling B., Macalalad A.: BioResources, 2017, 12, 3001. https://doi.org/10.15376/biores.12.2.3001-3016

[15] Yang J., Yu M., Chen W.: J. Ind. Eng. Chem., 2015, 21, 414. https://doi.org/10.1016/j.jiec.2014.02.054

[16] Wanees S., Ahmed A., Adam M., Mohamed M.: Asian J. Chem., 2013, 25, 8245. https://doi.org/10.14233/ajchem.2013.13559

[17] Bhanvase B., Ugwekar R. (Eds.): Process Modeling,

Simulation, and Environmental Applications in Chemical Engineering, Apple Academic Press, New York 2016.

https://doi.org/10.1201/9781315366449

[18] Cruz G., Pirilä M., Huuhtanen M. et al.: J. Civil. Environ. Eng., 2012, 2, 109. https://doi.org/10.4172/2165-784X.1000109

[19] Dubinin M.: Carbon, 1985, 23, 373.

https://doi.org/10.1016/0008-6223(85)90029-6

[20] National Research Council. Drinking Water and Health, vol. 2. The National Academies Press, Washington

1983.https://www.ncbi.nlm.nih.gov/books/NBK234593/

[21] Patil S., Natarajan G., Bhole A.: Indian J. Environ. Health, 2006, 48, 203.

[22] Kang Y., Toh S., Monash P. et al.: Asia-Pac. J. Chem. Eng., 2013, 8, 811. https://doi.org/10.1002/apj.1725

[23] Tan G., Xiao D.: J. Hazard. Mater., 2009, 164, 1359.

https://doi.org/10.1016/j.jhazmat.2008.09.082

[24] Dula T., Siraj K., Kitte S.: Int. Scholarly Res. Notice., 2014, 2014. https://doi.org/10.1155/2014/438245

[25] Ho Y., Mckay G.: Process Biochem., 1999, 34, 451.

https://doi.org/10.1016/S0032-9592(98)00112-5

Received: May 27, 2019 / Revised: July 13, 2019 / Accepted: September 25, 2019

\section{КІНЕТИКА ТА ІЗОТЕРМІЧНІ ДОСЛІДЖЕННЯ АДСОРБЦІЇ ШЕСТИВАЛЕНТНОГО ХРОМУ З ВИКОРИСТАННЯМ АКТИВОВАНОГО ВУГІЛЛЯ 3 ВОДНОГО ГІАЦИНТУ}

\begin{abstract}
Анотація. Для видалення $\mathrm{Cr}(V I)$ з водного розчину як адсорбент використано активоване вугілля, отримане з водного гіацинту (WH-AC). Визначено, що оптимізований WH-AC $\epsilon$ мезопористим та зернистим. Встановлено, щчо площа

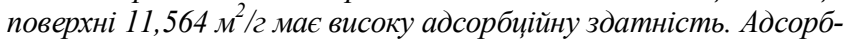
ція оптимізованого WH-АC відповідає кінетииі псевдодругого порядку та ізотермічній моделі Фрейндліха. Базуючись на коефіцієнті кореляиії, одержаним з кінетичної моделі псевдодругого порядку, отримані значення $R^{2}$ мали значення вище 0,99, щзо вказує на хемосорбиійність процесу. Встановлено, щуо адсорбиійна здатність WH-АC збільшується з 1,98 до 4,68 мг/2, з підвищенням кониентрації адсорбату з 20 до 50 мг/л. Показано, щчо адсорбиія активованим вугіллям, одержуваним з водного гіацинта, може бути альтернативним та ефективним методом для видалення шестивалентного хрому.
\end{abstract}

Ключові слова: адсорбиія, шестивалентний хром, кінетика, ізотерма, водний гіаџинт. 